\title{
Linking Biomass Productivity to Genotype-Specific Nutrient Cycling Strategies in Mature Hybrid Poplars Planted Along an Environmental Gradient
}

\author{
Julien Fortier $^{1}$ (D) Benoit Truax ${ }^{1}$ - Daniel Gagnon ${ }^{1,2}$ • France Lambert $^{1}$
}

Published online: 21 June 2017

(C) The Author(s) 2017. This article is an open access publication

\begin{abstract}
This study used three hybrid poplar (Populus $\times$ spp.) clones (13 years old) with different parentages planted in three abandoned farmland sites along a regional gradient of elevation and soil fertility in southern Québec (Canada). We evaluated the effects of plantation site and clone on nutrient concentrations in green foliage and leaf litter, on leaf litter mass remaining, on soil properties and on biomass yield. Green foliage and leaf litter nutrient concentrations, and litter decomposition, are under strong genetic and environmental control in hybrid poplars. Clone-specific correlation patterns between green foliage and leaf litter nutrient concentrations were observed, as well as between soil nutrient availability and foliage or leaf litter nutrient concentrations. Despite the wide variations in soil nutrient availability and elevation between sites, only the clone effect was significant on biomass yield. An increase in $\mathrm{N}$ and $\mathrm{P}$ resorption proficiency with
\end{abstract}

Electronic supplementary material The online version of this article (doi:10.1007/s12155-017-9850-7) contains supplementary material, which is available to authorized users.

Julien Fortier

fortier.ju@gmail.com

Benoit Truax

btruax@frfce.qc.ca

Daniel Gagnon

daniel.gagnon@uregina.ca

France Lambert

france.lambert@frfce.qc.ca

1 Fiducie de recherche sur la forêt des Cantons-de-l'Est / Eastern Townships Forest Research Trust, 1 rue Principale,

Saint-Benoît-du-Lac, QC J0B 2M0, Canada

2 Department of Biology, University of Regina, 3737 Wascana Parkway, Regina, SK S4S 0A2, Canada declining soil $\mathrm{NO}_{3}$ and $\mathrm{P}$ availability, observed in all clones, could explain stable yields of each clone across sites. The most productive clones $(\mathrm{DN} \times \mathrm{M}-915508$ and $\mathrm{M} \times \mathrm{B}$ 915311) were more proficient at resorbing $\mathrm{N}, \mathrm{P}$ and $\mathrm{K}$, while the least productive clone $(\mathrm{D} \times \mathrm{N}-131)$ had the highest $\mathrm{N}, \mathrm{P}$ and $\mathrm{K}$ concentrations in green foliage and in litter. The ability of clone $\mathrm{M} \times \mathrm{B}-915311$ to maintain high litter $\mathrm{Ca}$ and $\mathrm{Mg}$ concentrations on sites with soil characterised by lower $\mathrm{pH}$, lower base saturation and lower nutrient availability $\left(\mathrm{NO}_{3}, \mathrm{P}\right.$, $\mathrm{Ca}$ and $\mathrm{Mg}$ ) may also be linked to its high and stable productivity. Differences in litter quality between clones did not yield significant differences in soil properties or in litter mass remaining after 2 years. However, short-term decay trajectories varied between clones. As litter mass remaining was strongly correlated to elevation, the plantation site significantly affected leaf litter mass remaining, which ranged from 4.5 to $35.5 \%$ between sites after 2 years.

Keywords Nutrient resorption proficiency $\cdot$ Litter decomposition (decay) $\cdot$ Litter mass remaining $\cdot$ Calcium and magnesium $\cdot$ Site fertility and elevation $\cdot$ Leaf nutrient concentrations

\section{Introduction}

Fast-growing hybrid poplar (Populus $\times$ spp.) plantations are a major source of biomass, wood and pulp production in the temperate and boreal zones of the world [1]. Future expansion of the areas planted with poplars is expected because afforested poplar plantations can also rapidly provide many other ecosystem services (phytoremediation, habitat creation, soil stabilisation, hydrological control, disturbance regulation) when they are strategically integrated to agroecosystems [2-4]. In many regions, hybrid 
poplars are increasingly planted on abandoned farmland to reduce land use competition with food production systems $[5,6]$. However, abandoned fields are often characterised by uneven site fertility at the regional scale $[5,7]$. Clones having conservative nutrient use strategies or having leaf litter that can induce positive feedbacks on soil fertility could be used to achieve interesting yields on the more marginal sites. Such a strategy would be more sustainable than the use of fertilisers, which have important economic and environmental costs $[8,9]$.

Recent studies have documented important site $\times$ clone interactions for biomass production across environmental gradients, with some clones being better adapted to lower fertility and colder sites. For example, in the northern temperate zones of Canada and Europe, clones from the hybrid between Populus deltoides and Populus nigra $(\mathrm{D} \times \mathrm{N}$ hybrid $)$ had been characterised as specialists since they were only productive in warm and fertile bottomland sites [5, 10]. Conversely, clones having a Populus maximowiczii parentage had been found to be generalists because of their good productivity across a relatively wide range of soil fertility and climatic conditions [5, 10]. Despite these observations, no clear link between potential clone-specific nutrient cycling strategies and pattern of productivity across environmental gradients has been made.

In general, tree species using soil nutrients more efficiently have a competitive advantage in nutrient-limited environments [11]. Resorption of nitrogen $(\mathrm{N})$, phosphorus $(\mathrm{P})$ and potassium $(\mathrm{K})$ from leaf tissues during senescence is among the key nutrient conservation strategies of plants [11]. Two indicators of nutrient resorption potential are distinguished: (1) nutrient resorption efficiency (i.e. the relative reduction in nutrient content or concentration between green and senesced leaves [12]) and (2) nutrient resorption proficiency (i.e. levels to which nutrients have been reduced in senescing leaves, independently of green foliage nutrient status [12]). Nutrient resorption efficiency and proficiency have both been shown to have phenotypic and genotypic sources of variation [12-14]. For example, mountain birch (Betula pubescens), an early-successional species, is more proficient at resorbing $\mathrm{N}$ on sites of lower fertility [13], while conifers generally show higher $\mathrm{N}, \mathrm{P}$ and $\mathrm{K}$ resorption proficiency than deciduous species $[12,13]$.

Nutrient concentrations in green foliage can also be a good indicator of the capacity of a plant species to be productive under low nutrient availability. High concentrations of N, P, K, calcium $(\mathrm{Ca})$ and magnesium $(\mathrm{Mg})$ in green foliage often coincide with the capacity for rapid growth in productive site conditions and an inability to sustain yield under nutrientlimiting conditions [15]. In terrestrial plants, positive relationships between green foliage and leaf litter N, P and K concentrations have equally been observed [14]. Thus, plant species reaching higher green leaf nutrient status would not only be less productive on lower quality sites, but they would also be less proficient at resorbing $\mathrm{N}, \mathrm{P}$ and $\mathrm{K}$, than species with lower foliar nutrient concentrations.

In the genus Populus, foliage nutrient concentrations and nutrient resorption proficiency (or leaf litter nutrient concentrations) have been shown to vary greatly between clones of the same hybrid, between hybrid types and between species [16-21]. Hybrid poplars resulting from the cross between $P$. deltoides and P. nigra, two species from the Aigeiros section, were shown to have especially high $\mathrm{N}, \mathrm{P}, \mathrm{K}$ and $\mathrm{Ca}$ concentrations in green foliage and/or in leaf litter, compared to other hybrid types. Thus, $P$. deltoides $\times P$. nigra hybrids tend to have lower nutrient resorption proficiency compared to clones having a parental species from the balsam poplar (Tacamahaca) section [17-19]. These trends are compatible with the general idea that species from richer/warmer habitats generally reach higher nutritional status in their foliage and litter [11], as both $P$. deltoides and P. nigra are typical species of warm temperate floodplain ecosystems, while several balsam poplars (e.g. Populus balsamifera, P. maximowiczii, Populus trichocarpa) are more widely distributed along temperate, boreal and Taïga riparian ecotones [22]. Further, variations in green foliage and leaf litter nutrient concentrations for a given clone are expected between poplar plantations growing on sites of contrasted fertility and acidity, given the high sensitivity of these leaf traits to fertilisation, liming and general site quality [23-25]. In a study of four sites with identical 6-year-old hybrid poplar plantations, the highest N, P, K, $\mathrm{Ca}$ and $\mathrm{Mg}$ concentrations in green foliage were observed on the site where the availability of each of these macronutrients was the highest in the soil [26]. Given that foliage and litter nutrient concentrations are generally positively correlated [14], it is reasonable to assume that different poplar clones would achieve lower nutrient resorption proficiency on higher fertility sites. However, greenhouse studies with poplars and aspen have shown inconsistent trends in nutrient resorption proficiency patterns in relation to experimental nutrient addition $[17,27]$. Also, what is not known is to what extent the nutrient resorption capacity of different hybrid poplar clones is plastic along environmental gradients, and also to what extent the resorption capacity of different clones is linked to overall biomass productivity on marginal agricultural lands. Clonespecific level of plasticity in $\mathrm{N}$ resorption was observed in response to fertilisation in P. tremuloides [27] and is expected between hybrid poplar clones of different parentages.

A large part of the nutritional demands of fast-growing plantations can also be met by the uptake of nutrients that are released back during leaf litter decomposition and mineralisation [28]. At the site level, poplar leaf litter decay has been shown to be influenced by genotypic and environmental factors, because both of these factors influence litter chemistry [20, 21, 29, 30]. However, although $\mathrm{N}$ fertilisation increased litter N, P and Ca concentrations of P. tremuloides, this treatment had no significant effect on the rate of litter 
decomposition after 4 years [25]. At the site level, patterns of litter mass remaining also tended to converge with time for several boreal and temperate tree species producing litter of contrasted quality [31]. Thus, although litter quality (initial N concentration) has been shown to significantly affect early decomposition rate in short rotation poplar coppices [20], rates of leaf litter decay of $P$. tremuloides and of several other boreal and temperate tree species have been shown to be more strongly driven by mean annual temperature (MAT) [32-34]. Microcosm studies have also documented the positive effect of temperature on decay rate in $P$. tremuloides litter [35]. No study has yet determined if climate is a more important driver of litter decomposition than the quality of the litter produced by different poplar clones or species in mature plantations under temperate climate. Because elevation is the main factor explaining temperature variations between upland sites of the study area (southern Québec) [36], a dominant influence of site elevation on litter decay should be expected in plantations located along a regional elevation gradient [31,33].

Over the years, leaf litter produced by trees can also create significant feedbacks on forest floor decomposition, on soil C storage and nutrient availability and, ultimately, on primary productivity $[31,37,38]$. In many ecosystems, nitrogen $(\mathrm{N})$ and phosphorus $(\mathrm{P})$ concentrations of leaf litter can positively affect litter decomposition, $\mathrm{N}$ release to the soil and thus primary productivity [37,39]. Leaf litter $\mathrm{Ca}$ is also a major driver of modification of soil properties through its indirect effect on the abundance and diversity of decomposer organisms, but also through its direct effect on pedogenesis [40]. In general, tree species having high litter Ca positively affect the abundance and diversity of earthworm species, soil acidity, soil fertility and forest floor turnover rate [40].

Field or greenhouse studies, mostly undertaken at the single site level, have documented the effect of changing environmental conditions and/or poplar species (or clone) on carbon (C) and nutrient cycling [16, 17, 19, 20, 25, 27]. In this study, we evaluated the effects of both an environmental gradient (elevation and soil fertility) and genetic source (poplar clones) on $\mathrm{C}$ and nutrient cycling (nutrient concentration in green foliage and in leaf litter, and leaf litter decomposition) and on soil properties (C, nutrient availability and $\mathrm{pH})$. A second objective was to evaluate the potential relationships between green leaf nutrient status, nutrient resorption proficiency (nutrient concentration in leaf litter) and soil nutrient availability for the different poplar clones. A final objective was to evaluate if aboveground biomass productivity could be linked to potentially different nutrient cycling strategies. To address these objectives, we measured green foliage nutrient concentrations, leaf litter nutrient concentrations and leaf litter decomposition (decay) of three hybrid poplar clones with different parental species in three 13-year-old plantations located along a regional gradient of elevation and soil fertility in the southern Québec (southeastern Canada) region, which belongs to the northern temperate zone. These foliar and litter traits were measured along with soil characteristics and aboveground woody biomass yield. The three hybrid poplar clones studied $(\mathrm{D} \times \mathrm{N}-131, \mathrm{M} \times \mathrm{B}-915311, \mathrm{DN} \times \mathrm{M}-915508)$ were selected because they represent different genetic assemblages of four parental species that have distinct natural distributions and ecological characteristics, ${ }^{1}$ and that are currently used for commercial purposes.

In this study, we tested the following hypotheses: (1) because poplar foliage and litter nutrient concentrations are generally affected by soil nutrient variations, green foliage and leaf litter nutrient concentrations of the three clones will reach maximum values at sites where soil nutrient availability is highest; (2) clone $\mathrm{D} \times \mathrm{N}-131$ will reach the highest nutritional status in green foliage and in leaf litter, and will have the lowest resorption proficiency for growth-limiting nutrients ( $\mathrm{N}$ and $\mathrm{P}$ ) and the lowest biomass production; and (3) the high quality litter produced by clone $\mathrm{D} \times \mathrm{N}-131$ will decompose the most rapidly at the site level, while higher litter mass remaining will be observed for all clones on higher elevation sites given that site elevation is a regional proxy for mean annual temperature.

\section{Materials and Methods}

\section{Study Sites and Experimental Design}

Three hybrid poplar plantation sites, located in the Eastern Townships region of southern Québec (eastern Canada), were used in this study (Brompton, La Patrie and Melbourne). These sites were chosen because they cover a large elevation gradient in the study area, from 170 up to $440 \mathrm{~m}$ above sea level, with higher MAT and lower mean annual precipitation (MAP) characterising lower elevation sites regionally (Table 1) [36]. Based on MAT data and site elevation of the nearest meteorological station [41], elevation was found to be a good proxy of MAT ( $r=0.99, p=0.08, n=3$ ). The three study sites were also selected from a larger pool of even-aged hybrid poplar plantations sites because they have contrasted soil characteristics [5] (Table 1). The three study sites are also located within a radius of $40 \mathrm{~km}$, with all plantation sites being nearly flat, with slopes under 5\%. The geology of the study area is complex, but the bedrock is almost completely covered with glacio-fluvial and glacial till deposits [42]. A continental sub-humid moderate climate characterises the study region [42].

\footnotetext{
${ }^{1}$ Clone $\mathrm{D} \times \mathrm{N}-131$ is a hybrid between $P$. deltoides (D) and P. nigra $(\mathrm{N})$, two species associated with riparian ecosystems of warm temperate zones [22]. Clone $\mathrm{M} \times \mathrm{B}-915311$ is a hybrid between $P$. maximowiczii $(\mathrm{M})$ and P. balsamifera (B), two species associated with riparian ecosystems of northern temperate, boreal and taiga ecozones, with P. balsamifera having the capacity to thrive at the northern limit of trees [22]. Clone $\mathrm{DN} \times \mathrm{M}-915508$ is the result of a cross between a $\mathrm{D} \times \mathrm{N}$ hybrid and $P$. maximowiczii.
} 
Table 1 Site and soil characteristics of hybrid poplar plantations. Sites identified with different letters are significantly different $(\alpha=0.05$; Tukey's HSD test)

\begin{tabular}{|c|c|c|c|c|c|c|c|c|c|c|c|c|}
\hline Sites & $\begin{array}{l}\text { Elevation } \\
\text { (m) }\end{array}$ & $\begin{array}{l}\mathrm{MAT}^{\mathrm{a}} \\
\left({ }^{\circ} \mathrm{C}\right)\end{array}$ & $\begin{array}{l}\mathrm{MAP}^{\mathrm{a}} \\
(\mathrm{mm} / \\
\text { year})\end{array}$ & $\begin{array}{l}\text { Soil } \\
\mathrm{pH}\end{array}$ & $\begin{array}{l}\text { Organic } \\
\text { matter } \\
(\%)\end{array}$ & $\begin{array}{l}\text { Total } \\
\mathrm{C} \\
(\mathrm{g} / \mathrm{kg})\end{array}$ & $\begin{array}{l}\text { Total } \\
\mathrm{N} \\
(\mathrm{g} / \mathrm{kg})\end{array}$ & $\mathrm{C}: \mathrm{N}$ & $\begin{array}{l}\text { Base } \\
\text { saturation } \\
(\%)\end{array}$ & $\begin{array}{l}\text { Clay } \\
(\%)\end{array}$ & $\begin{array}{l}\text { Silt } \\
(\%)\end{array}$ & $\begin{array}{l}\text { Sand } \\
(\%)\end{array}$ \\
\hline Brompton & 170 & 5.6 & 1146 & $5.67 \mathrm{a}$ & $4.60 \mathrm{~b}$ & $21.5 \mathrm{~b}$ & $2.54 \mathrm{~b}$ & $8.5 \mathrm{a}$ & $47.9 \mathrm{a}$ & 24 & 49 & 27 \\
\hline La Patrie & 440 & 4.0 & 1370 & $5.16 \mathrm{c}$ & $4.82 \mathrm{~b}$ & $24.5 \mathrm{~b}$ & $2.51 \mathrm{~b}$ & $9.8 \mathrm{~b}$ & $30.2 \mathrm{~b}$ & 16 & 47 & 37 \\
\hline Melbourne & 330 & 4.7 & 1232 & $5.43 \mathrm{~b}$ & $6.93 \mathrm{a}$ & $33.9 \mathrm{a}$ & $3.07 \mathrm{a}$ & $11.0 \mathrm{~b}$ & $26.3 \mathrm{~b}$ & 14 & 37 & 49 \\
\hline SE & & & & 0.05 & 0.24 & 1.7 & 0.12 & 0.2 & 2.4 & & & \\
\hline$p<$ & & & & 0.001 & 0.001 & 0.001 & 0.01 & 0.001 & 0.001 & & & \\
\hline
\end{tabular}

${ }^{a}$ Mean annual temperature (MAT) and mean annual precipitation (MAP) for the 1981-2010 period were obtained from the nearest meteorological station (within a 25-km radius from each study site). For the Brompton site, data from the Bromptonville station (130 $\mathrm{m}$ of elevation) were used. For the La Patrie site, data from the Notre-Dame-des-Bois station (502 m of elevation) were used. For the Melbourne site, data from the Bonsecours station (297 $\mathrm{m}$ of elevation) were used

When the study was initiated (2012), all plantations were in their 13th growing season. Pre-plantation site preparation included ploughing and disking each site in fall 1999. In the spring of 2000, bare-root planting stock with 2-m-long stems were planted manually with shovels at 30 to $40 \mathrm{~cm}$ depth at a spacing of $3 \mathrm{~m} \times 4 \mathrm{~m}$. Planting stock (1-0) was provided by the Berthierville nursery of the Ministère des Ressources naturelles - Forêt (MRNF) of Québec. Competing vegetation was eliminated with glyphosate herbicide application over the entire plantation area in June 2000 and between plantation rows only, in June 2001.

The initial experimental design contained eight plantation sites, with three blocks per site, and nine poplar clones. However, for the purposes of this study, only three clones (with contrasted parentages) and three sites were used. These three unrelated hybrid poplar clones are (1) $\mathrm{D} \times \mathrm{N}-131$, a $P$. deltoides $\times P$. nigra hybrid (also named $P . \times$ canadensis); (2) $\mathrm{DN} \times \mathrm{M}-915508$, a $P . \times$ canadensis $\times P$. maximowiczii hybrid; and (3) $\mathrm{M} \times \mathrm{B}-915311$, a $P$. maximowiczii $\times P$. balsamifera hybrid. These clones were developed in Québec and had been selected for superior disease resistance/tolerance and growth characteristics in MRNF genetic selection trials in southern Québec [43]. A randomised block design was used at each of the three sites, with three blocks (nested in sites) and three plots per block (one plot per hybrid poplar clone), for a total of 27 experimental plots ( 3 sites $\times 3$ blocks $\times 3$ clones, $n=27)$. Plots are $12 \mathrm{~m}$ wide and $12 \mathrm{~m}$ long $\left(144 \mathrm{~m}^{2}\right)$. Each plot initially contained 12 trees from a single clone (3 rows with 4 trees per row). Trees are spaced $3 \mathrm{~m}$ apart on the row, and the rows are $4 \mathrm{~m}$ apart (tree density of $833 \mathrm{stems} / \mathrm{ha}$ ).

\section{Mineral Soil Characteristics}

In each plot, soil samples (20 $\mathrm{cm}$ depth) were obtained by extracting and combining two soil cores (diameter $=5.2 \mathrm{~cm}$, length $=20 \mathrm{~cm}$ ) from the soil surface. Soil samples were air dried and sieved $(2 \mathrm{~mm})$. Soil C concentrations were determined by the combustion method at high temperature $\left(960{ }^{\circ} \mathrm{C}\right)$ followed by thermal conductivity detection. These analyses were done by the CEF lab (Dr. R. Bradley and Dr. W. Parsons) at the University of Sherbrooke. Soil $\mathrm{pH}$, clay, silt and sand content, percent organic matter and base saturation were determined by the Agridirect Inc. soil analysis lab in Longueuil (Québec). Methods used are those recommended by the Conseil des productions végétales du Québec [44]. Soil pH was assessed using a 1:1 ratio of distilled water to soil. For particle size analyses, the Bouyoucos [45] method was used, and plot level soil samples were combined at the block level prior to analysis. Percent organic matter was determined by weight loss after ignition at $550{ }^{\circ} \mathrm{C}$ for $4 \mathrm{~h}$. Base saturation was calculated following the recommendations of the Centre de référence en agriculture et agroalimentaire du Québec [46], after Ca, K and $\mathrm{Mg}$ extraction with the Mehlich III method [47] and concentration determination using ICP emission spectroscopy [48].

\section{Nutrient Supply Dynamics}

Nutrient availability in the entire experimental design was determined using Plant Root Simulator (PRS ${ }^{\mathrm{TM}}$ probes) technology from Western Ag Innovations Inc., Saskatoon (SK), Canada. The PRS probes consist of ion exchange membranes (adsorbing surface area of $17.5 \mathrm{~cm}^{2} /$ probe) encapsulated in a thin plastic probe, which is inserted into the $0-10-\mathrm{cm}$ depth range with little disturbance of soil structure. During the burial period, the PRS probe membrane adsorbs nutrients that are already available along with nutrients that are converted to the available form. Each pair of probes consists of an anion and a cation exchange membrane. Nutrient supply rates measured with PRS probes are generally strongly correlated with soil nutrient concentrations and stocks measured using 
conventional extraction methods in agricultural studies and in hybrid poplar plantations $[49,50]$. In each plot, four pairs of probes were buried in the A horizon for three consecutive burial time periods of 42 days during the growing season: (1) from May 16 to June 27, 2013; (2) from June 27 to August 8, 2013; and (3) from August 8 to September 19, 2013. A total of 81 PRS probes samples were collected ( 3 sites $\times 3$ blocks/site $\times 3$ clones/block $\times 3$ sampling periods) . After probes were removed from the soil, they were washed in the field with distilled water and returned to Western Ag Labs for analysis $\left(\mathrm{NO}_{3}, \mathrm{NH}_{4}, \mathrm{P}, \mathrm{K}, \mathrm{Ca}\right.$ and $\left.\mathrm{Mg}\right)$. Composite samples were made in each plot by combining the four pairs of probes. Nutrient supply rates at each site are reported as micrograms of nutrient per $10 \mathrm{~cm}^{2}$ per 42 days.

\section{Aboveground Woody Biomass Yield}

At the end of the 13th growing season, diameter at breast height (DBH, at $1.3 \mathrm{~m}$ ) of each living tree in the experimental design was measured using a caliper (mean of two diameter measurements taken perpendicularly). $\mathrm{DBH}$ measurements were taken from late October to early November 2012. For each living tree, aboveground woody biomass was calculated by inserting the DBH value in the selected clone-specific allometric relationships developed by Truax et al. [51]. These relationships had been developed for 13-year-old poplars in a larger experimental design that included the studied sites. For clone $\mathrm{D} \times \mathrm{N}-131$, no clone-specific equation was available, so the equation developed for a different clone of the same parentage (clone $\mathrm{D} \times \mathrm{N}-3570$ ) was used. Then, total plot aboveground biomass was calculated by summing the biomass of individual living trees in the plot. Total biomass yield data per plot were then scaled up to 1 ha and divided by poplar age (13 years) in order to produce mean annual yield data.

\section{Green Foliage Sampling}

At the end of July 2012, green foliage samples were collected in each plot. At this time during summer, nutrient concentrations are at their maximum in the foliage of hybrid poplars [18]. Each sample was collected by cutting down two branches (using a long ladder and a telescopic pruning pole), one from the upper canopy section and one from the lower canopy section, of two healthy representative poplars (average size) per plot. All completely formed leaves of average size were removed from the branch samples and combined to produce a single composite sample per plot. Leaf samples were air dried prior to grinding, and ground samples were taken back to the lab to determine $\mathrm{C}$ and nutrient concentrations of oven-dried $\left(65^{\circ} \mathrm{C}\right)$ subsamples.

\section{Leaf Litter Sampling and Decomposition Study}

At the end of the 13th growing season (in late October 2012), newly shed leaf litter was collected on the plantation forest floor in each plot $[52,53]$. Care was taken to choose average sized leaves that had only recently fallen. All leaf litter samples were air dried to constant mass and subsamples were analysed to determine $\mathrm{C}$ and nutrient concentrations (on an oven-dry mass basis at $65^{\circ} \mathrm{C}$ ), as well as water content.

Decomposition of hybrid poplar leaf litter was evaluated using the mesh bag method [54]. Litterbags $(20 \mathrm{~cm} \times 12.5 \mathrm{~cm})$ were prepared with polyethylene screen of $1 \mathrm{~mm}$ mesh size in order to minimise loss of litter fragments [55]. On each litter bag, eight larger round openings $(d=5 \mathrm{~mm})$ were made, with a punch, on both faces of the litterbags to facilitate access of micro- and macro-arthropods, soil molluscs (snails and slugs) and juvenile Lumbricus species [53, 56, 57]. Litterbags were filled with a precisely weighed quantity of air-dried litter (approximately $3 \mathrm{~g}$, or 8 to 15 leaves, depending on the poplar clone). An air-dried to oven-dried $\left(65^{\circ} \mathrm{C}\right)$ conversion factor was calculated and then used to obtain the oven-dry mass of the initial leaf litter material placed in litterbags.

On November 7, 2012, a series of eight litterbags was placed in each plot (within a $1-\mathrm{m}^{2}$ area), for a total of 216 litterbags. Litterbags were then partly covered with leaf litter found in the plot. During the first incubation year, litterbags were collected monthly (approximately), starting May 16, 2013, and ending October 22, 2013, for a total of six litterbags per plot collected in 2013. In each plot, two remaining litterbags were left for data collection over a second year. These were collected on May 27, 2014, and on November 7, 2014 (after 2 years). Once collected, litterbags were air dried for a week and then opened. Soil particles, vegetation debris (roots, moss and herbaceous vegetation), macroinvertebrates and spider nests were removed with tweezers [58]. Leaf litter samples were then gently washed with tap water to remove adhering soil particles [58]. Litter samples were then oven dried $\left(65^{\circ} \mathrm{C}\right)$ until constant mass was achieved to determine the remaining mass. Leaf litter decay data are expressed in percent of initial mass remaining (on an oven-dried mass basis).

\section{Nutrient Dynamics in Leaf Litter and Green Foliage}

Because leaves experience mass loss and surface area shrinkage during senescence, we did not calculate resorption efficiency based on nutrient concentrations measured in green foliage and leaf litter, because such a calculation would have led to an underestimation of actual resorption efficiency [59]. Instead, we calculated an index of nutrient resorption efficiency, expressed as the nutrient concentration in leaf litter as a percentage of that found in green foliage [60]. Additionally, the concept of nutrient resorption proficiency (i.e. levels to which nutrients have been reduced in senescing leaves before 
abscission, independently of green foliage nutrient status [12]) was used to interpret leaf litter nutrient concentration data, as it is argued to be a more definitive measure of the degree to which natural selection has acted to minimise nutrient loss [12]. Finally, the N:P ratio in green foliage and in leaf litter was calculated, as changes between the N:P ratio in green foliage vs. the N:P ratio in leaf litter provides an unbiased indicator of the differential resorption efficiency between $\mathrm{N}$ and $\mathrm{P}[61]$.

\section{Chemical Analysis of Plant Tissues}

Green foliage and leaf litter subsamples were ground in a mill (Pulverisette 15, Fritsch) to a particle size of $<0.5 \mathrm{~mm}$ to insure adequate sample homogeneity. Nutrient concentrations ( $\mathrm{P}, \mathrm{K}, \mathrm{Ca}$ and $\mathrm{Mg}$ ) were determined by the calcination method [48] at the Agridirect Laboratory, Longeuil (QC, Canada). Total $\mathrm{C}$ and $\mathrm{N}$ concentrations of samples were determined by high-temperature combustion $\left(960{ }^{\circ} \mathrm{C}\right)$, followed by thermo-conductometric detection, on a Vario Macro analyser (Elementar Analysensysteme, Hanau, Germany). Measurements were standardised against glutamic acid, together with checks on $\mathrm{N}$ recovery using NIST (National Institute of Standards and Technology, Gaithersburg, MD) reference materials (Citrus 1572, Apple 1515). Carbon and $\mathrm{N}$ analyses were conducted by the Centre d'étude de la forêt laboratory at the University of Sherbrooke (QC, Canada).

\section{Statistical Analyses}

All data were analysed using a two-way ANOVA in a fixed factorial design [62]. ANOVA tested main effects (site and clone) and the interaction effect (site $\times$ clone). When an effect was declared statistically significant $(p<0.05, p<0.01$ and $p<0.001$ ), the Tukey's HSD test was used to declare significant differences between means $(\alpha=0.05)$ [63]. All of the ANOVAs were run with the complete data set. Being proportions, leaf litter remaining mass data were logit-transformed prior to ANOVA [64], and two-way ANOVAs were run individually for each point in time corresponding to litterbag retrieval. However, proportional data are presented in percentage values in the tables and figures. Nutrient concentration change in leaf litter vs. green foliage data were not transformed prior to ANOVA because values above $100 \%$ were frequently observed. Nutrient supply rates measured in the experimental design over three consecutive 42-day periods were averaged to produce a single observation in each plot. A MANOVA was used to test site, clone and leaf status (green foliage vs. leaf litter) main effects and interaction effects on the N:P ratio. The Pearson product-moment correlation coefficient $(r)$ was used to evaluate potential associations between pairs of ecologically meaningful variables. All statistical analyses were done using JMP 11 from SAS Institute (Cary, NC).

\section{Results}

\section{Soil Characteristics and Soil Nutrient Supply Rates}

No clone effect and no site $\times$ clone interaction were observed on soil variables. Site effects were significant for all soil variables studied (Tables 1 and 2). Compared to the other sites, the soil of the Brompton site (located at the lowest elevation, $170 \mathrm{~m}$ ) had a significantly higher soil $\mathrm{pH}$ and a significantly lower $\mathrm{C}: \mathrm{N}$ ratio, and significantly higher base saturation and $\mathrm{NO}_{3}$ supply rate (Tables 1 and 2). The soil at the Melbourne site was characterised by the highest organic matter, $\mathrm{C}$ and $\mathrm{N}$ concentration. The soil of the La Patrie site (located at the highest elevation, $440 \mathrm{~m}$ ) was characterised by the lowest soil $\mathrm{pH}$ and soil $\mathrm{NO}_{3}$ supply rate and the highest soil $\mathrm{NH}_{4}$ supply rate (Tables 1 and 2). The $\mathrm{P}$ supply rates at the Brompton and Melbourne sites were statistically different, with the highest value observed at Brompton. The same trend was observed for the $\mathrm{Ca}$ supply rate. For several soil properties (C:N ratio, base saturation, $\mathrm{NO}_{3}, \mathrm{P}, \mathrm{Ca}$ and $\mathrm{K}$ supply rates), the La Patrie and Melbourne sites were not statistically different.

\section{Aboveground Biomass Yield}

Only a significant clone effect $(p<0.01)$ was observed on aboveground biomass yield, with clone $\mathrm{D} \times \mathrm{N}-131$ being

Table 2 Site effect for mean nutrient supply rates $\left(\mu \mathrm{g} / 10 \mathrm{~cm}^{2} / 42\right.$ days) measured during the growing season over three consecutive 42 -day periods in poplar plantations. Sites identified with different letters are significantly different ( $\alpha=0.05$; Tukey's HSD test)

\begin{tabular}{|c|c|c|c|c|c|c|c|}
\hline Sites & $\mathrm{NO}_{3}$ & $\mathrm{NH}_{4}$ & $\mathrm{NO}_{3}: \mathrm{NH}_{4}$ (molar ratio) & $\mathrm{P}$ & $\mathrm{Ca}$ & $\mathrm{K}$ & $\mathrm{Mg}$ \\
\hline Brompton & $63.6 \mathrm{a}$ & $4.22 \mathrm{~b}$ & 4.38 & $5.37 \mathrm{a}$ & $2347 \mathrm{a}$ & $18.9 \mathrm{~b}$ & $302 \mathrm{a}$ \\
\hline La Patrie & $5.1 \mathrm{~b}$ & $6.82 \mathrm{a}$ & 0.22 & $3.59 \mathrm{ab}$ & $2150 \mathrm{ab}$ & $25.7 \mathrm{ab}$ & $192 b$ \\
\hline Melbourne & $9.4 \mathrm{~b}$ & $5.06 \mathrm{~b}$ & 0.54 & $1.23 \mathrm{~b}$ & $1863 \mathrm{~b}$ & $41.3 \mathrm{a}$ & $256 \mathrm{a}$ \\
\hline SE & 9.5 & 0.31 & - & 0.75 & 93 & 5.8 & 12.8 \\
\hline$p<$ & 0.01 & 0.001 & - & 0.01 & 0.05 & 0.05 & 0.001 \\
\hline
\end{tabular}


significantly less productive than both $P$. maximowiczii hybrids (Fig. 1).

\section{Green Foliage and Leaf Litter Nutrient Concentration}

A few significant site $\times$ clone interactions were observed (Table 3). Litter Ca of clone $\mathrm{D} \times \mathrm{N}-131$ varied little across the three sites $(2.42-2.53 \%)$, compared to clone DN $\times$ M$915508(2.03-2.53 \%)$ and clone $\mathrm{M} \times \mathrm{B}-915311$ (3.38$3.91 \%$ ), which had the highest litter $\mathrm{Ca}$ concentration at each site. The highest litter $\mathrm{Ca}$ value was observed at Brompton for clone $\mathrm{D} \times \mathrm{N}-131(2.53 \%)$ and for clone $\mathrm{DN} \times \mathrm{M}-915508$ $(2.53 \%)$, but at Melbourne for clone $\mathrm{M} \times \mathrm{B}-915311$ $(3.91 \%)$. A slightly different pattern was observed for litter $\mathrm{Mg}$, with the highest value being observed at Brompton for clone $\mathrm{D} \times \mathrm{N}-131(0.507 \%)$ and for clone $\mathrm{DN} \times \mathrm{M}-915508$ (0.520\%), but at La Patrie for clone M $\times$ B-915311 (0.493\%). Additionally, much higher variation in the $\mathrm{Ca}$ litter:foliage concentration ratio was found for clone $\mathrm{M} \times \mathrm{B}-915311$ across the study sites (98-170\%), compared to clone $\mathrm{DN} \times \mathrm{M}$ 915508 (105-121\%) and clone D $\times$ N-131 (83-95\%). A similar pattern also occurred for litter $\mathrm{Mg}$ and the $\mathrm{Mg}$ litter:foliage concentration ratio, as indicated by a significant site $\times$ clone interaction (Table 3 ). A significant site $\times$ clone interaction was equally observed for the $\mathrm{N}$ litter:green foliage concentration ratio in leaf litter $(p<0.05)$, with clone $\mathrm{DN} \times \mathrm{M}-915508$ having the lowest variation across the study sites $(32-36 \%)$, compared to clone $\mathrm{M} \times \mathrm{B}-915311(34-61 \%)$ and clone $\mathrm{D} \times \mathrm{N}$ 131 (44-56\%), with maximal values for each clone all observed at Brompton. Finally, a significant site $\times$ clone interaction was observed for the green foliage $\mathrm{C}$ concentration $(p<0.05)$ (Table $\mathrm{S} 1)$. A significant site $\times$ clone $\times$ leaf status interaction was also observed for the N:P ratio $(p<0.01)$. While differences in the N:P ratio of green foliage vs. N:P ratio in leaf litter were small for all clones at the richest site (Brompton), the leaf litter N:P ratio was approximately double that of the green foliage N:P ratio for clone $\mathrm{DN} \times \mathrm{M}-915508$ on the least fertile sites (Melbourne and La Patrie), a trend not

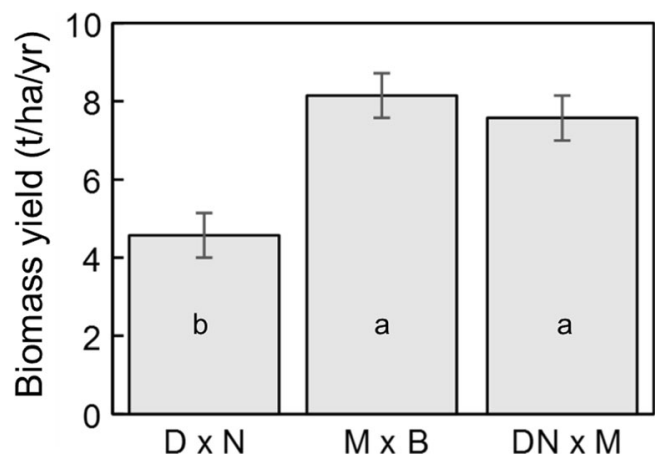

Fig. 1 Clone effect $(p<0.01)$ on aboveground woody biomass yield. Vertical bars represent SE and clones identified with different letters are significantly different ( $\alpha=0.05$; Tukey's HSD test) observed for the other clones. For clone $\mathrm{M} \times \mathrm{B}-915311$, litter $\mathrm{N}: \mathrm{P}$ ratio was lower than green foliage $\mathrm{N}: \mathrm{P}$ ratio, but only at the Melbourne site.

For most green foliage and leaf litter nutrient concentrations measured in this study, significant clone effects were also observed (Table 3). Data at the clone level (three site mean) suggest that clone $\mathrm{D} \times \mathrm{N}-131$ had the highest green foliage nutrient concentrations for $\mathrm{N}, \mathrm{P}, \mathrm{K}, \mathrm{Ca}$ and $\mathrm{Mg}$. However, leaf litter nutrient concentration of clone $\mathrm{D} \times \mathrm{N}-131$ was the highest only for N, P and K. For leaf litter N and P concentrations, clone ranking was as follows: $\mathrm{DN} \times \mathrm{M}$ $915508<\mathrm{M} \times \mathrm{B}-915311<\mathrm{D} \times \mathrm{N}-131$. However, while $\mathrm{N}$ and $\mathrm{P}$ concentrations in green foliage of clone $\mathrm{D} \times \mathrm{N}-131$ were the highest among the three clones, these values were similar for clone $\mathrm{DN} \times \mathrm{M}-915508$ and clone $\mathrm{M} \times \mathrm{B}-915311$. Clone effects were also observed for nutrient concentration change in leaf litter vs. green foliage. Clone $\mathrm{DN} \times \mathrm{M}-915508$ had the lowest litter:green foliage concentration ratios for $\mathrm{N}(34 \%), \mathrm{P}$ (20\%), K (24\%) and Mg (92\%), while clone D × N-131 had the highest values for N (49\%), P (55\%) and K (44\%).

Several site effects were also observed for green foliage and leaf litter nutrient concentrations. Green foliage $\mathrm{P}, \mathrm{Ca}$ and $\mathrm{Mg}$, as well as leaf litter $\mathrm{N}, \mathrm{P}$ and $\mathrm{Mg}$ were highest at Brompton (Table 3), while green foliage and leaf litter $\mathrm{C}$ were the lowest at this site (Table S1). Concerning the $\mathrm{N}$ and $\mathrm{P}$ litter:green foliage nutrient concentration ratio, significantly higher values were also found at Brompton, while green foliage N:P ratio was significantly higher at Melbourne.

\section{Correlations Between Leaf Litter and Green Foliage Nutrient Concentration}

Several significant positive correlations between green foliage and leaf litter nutrient concentration were found for clones $\mathrm{D} \times \mathrm{N}-131$ and $\mathrm{DN} \times \mathrm{M}-915508$, but not for clone $\mathrm{M} \times \mathrm{B}-$ 915311 (Table 4). While green foliage and leaf litter $\mathrm{Ca}$ or $\mathrm{Mg}$ were positively correlated for clone $\mathrm{D} \times \mathrm{N}-131$ and $\mathrm{DN} \times \mathrm{M}$ 915508 , these traits were negatively correlated for clone $\mathrm{M} \times \mathrm{B}-915311$. Litter $\mathrm{N}$ was positively correlated to litter $\mathrm{P}$, but negatively correlated to litter $\mathrm{Ca}$ and $\mathrm{Mg}$ for clone $\mathrm{M} \times \mathrm{B}$ 915311. For this clone, litter $\mathrm{P}$ was also negatively correlated to litter $\mathrm{Ca}$, which contrasts with the positive association observed between these two traits for clone $\mathrm{DN} \times \mathrm{M}-915508$. No significant correlation was observed between litter nutrient concentrations for clone $\mathrm{D} \times \mathrm{N}-131$.

\section{Correlations Between Soil Nutrient Supply Rate and Green Foliage or Leaf Litter Nutrient Concentrations}

Correlation patterns between soil nutrient supply and green foliage or leaf litter nutrient concentrations were clonespecific (Table 4). The most striking results were observed for clone $\mathrm{M} \times \mathrm{B}-915311$, with soil $\mathrm{NO}_{3}$ being positively 


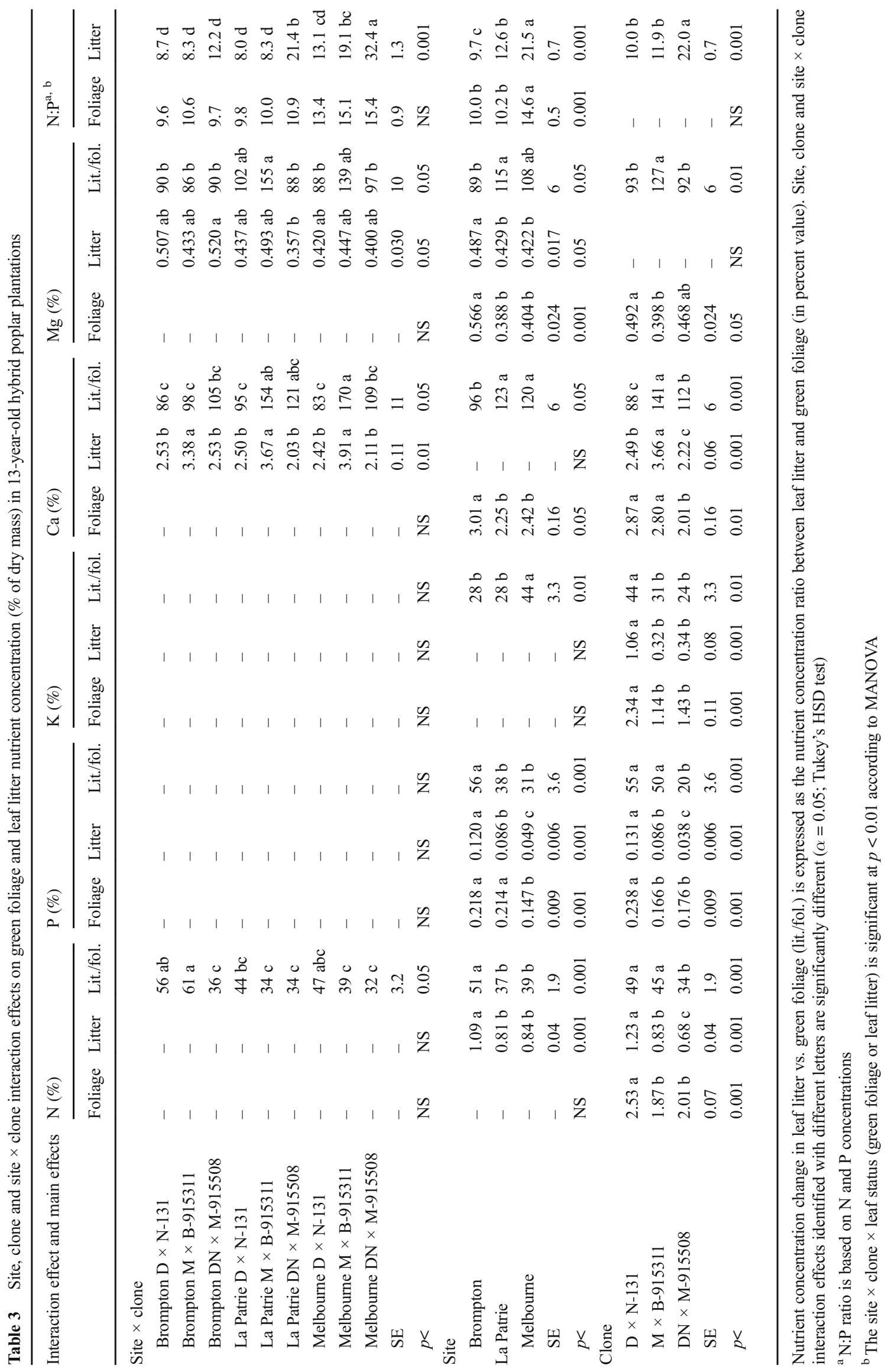


Table 4 Pearson correlation coefficients $(r)$, for each clone, between green foliage and leaf litter nutrient concentrations, among leaf litter nutrient concentrations and between soil nutrient supply rates and green foliage or leaf litter nutrient concentrations $(* * * p<0.001$, $* * p<0.01, * p<0.05$ and $\left.{ }^{\dagger} p<0.1\right)$

\begin{tabular}{|c|c|c|c|}
\hline \multirow[t]{2}{*}{ Variables } & \multicolumn{3}{|l|}{ Clones } \\
\hline & $\mathrm{D} \times \mathrm{N}-131$ & $\mathrm{M} \times \mathrm{B}-915311$ & $\mathrm{DN} \times \mathrm{M}-915508$ \\
\hline \multicolumn{4}{|c|}{ Green foliage vs. leaf litter nutrient concentration } \\
\hline Foliage C vs. litter C & $0.81 * *$ & ns & $0.69 *$ \\
\hline Foliage $\mathrm{N}$ vs. litter $\mathrm{N}$ & ns & ns & ns \\
\hline Foliage P vs. litter P & $0.80^{*}$ & ns & $0.85 * *$ \\
\hline Foliage $\mathrm{K}$ vs. litter $\mathrm{K}$ & $0.76^{*}$ & ns & ns \\
\hline Foliage $\mathrm{Ca}$ vs. litter $\mathrm{Ca}$ & $0.68 *$ & $-0.64^{\dagger}$ & $0.88 * *$ \\
\hline Foliage $\mathrm{Mg}$ vs. litter $\mathrm{Mg}$ & $0.69^{*}$ & $-0.67 *$ & $0.91 * * *$ \\
\hline \multicolumn{4}{|c|}{ Leaf litter vs. leaf litter nutrient concentration } \\
\hline Litter N vs. litter P & ns & $0.85 * *$ & ns \\
\hline Litter $\mathrm{N}$ vs. litter $\mathrm{Ca}$ & ns & $-0.64^{\dagger}$ & $0.63^{\dagger}$ \\
\hline Litter N vs. litter Mg & ns & $-0.59^{\dagger}$ & ns \\
\hline Litter P vs. litter $\mathrm{Ca}$ & ns & $-0.75^{*}$ & $0.87 * *$ \\
\hline Litter P vs. litter Mg & ns & ns & ns \\
\hline \multicolumn{4}{|c|}{ Soil nutrient supply vs. green foliage nutrient concentration } \\
\hline Soil $\mathrm{NO}_{3}$ vs. foliage $\mathrm{N}$ & ns & ns & ns \\
\hline Soil P vs. foliage P & $0.73 *$ & ns & $0.72 *$ \\
\hline Soil K vs. foliage K & ns & ns & ns \\
\hline Soil Ca vs. foliage $\mathrm{Ca}$ & ns & $0.65^{\dagger}$ & $\mathrm{ns}$ \\
\hline Soil Mg vs. foliage $\mathrm{Mg}$ & $0.71^{*}$ & ns & $0.69^{*}$ \\
\hline Soil $\mathrm{NO}_{3}$ vs. foliage $\mathrm{Ca}$ & ns & $0.92 * * *$ & ns \\
\hline Soil $\mathrm{NO}_{3}$ vs. foliage $\mathrm{Mg}$ & $0.60^{\dagger}$ & $0.87 * *$ & $0.58^{\dagger}$ \\
\hline Soil P vs. foliage $\mathrm{Ca}$ & ns & ns & ns \\
\hline Soil P vs. foliage $\mathrm{Mg}$ & ns & ns & ns \\
\hline \multicolumn{4}{|c|}{ Soil nutrient supply vs. leaf litter nutrient concentration } \\
\hline Soil $\mathrm{NO}_{3}$ vs. litter $\mathrm{N}$ & ns & $0.86^{* *}$ & $0.87 * *$ \\
\hline Soil P vs. litter P & $0.84 * *$ & $0.82 * *$ & ns \\
\hline Soil K vs. litter K & $0.68^{*}$ & $0.62^{\dagger}$ & $\mathrm{ns}$ \\
\hline Soil Ca vs. litter $\mathrm{Ca}$ & ns & ns & $0.74 *$ \\
\hline Soil Mg vs. litter Mg & $0.61^{\dagger}$ & ns & $0.72 *$ \\
\hline Soil $\mathrm{NO}_{3}$ vs. litter $\mathrm{Ca}$ & $\mathrm{ns}$ & $-0.59^{\dagger}$ & $0.74 *$ \\
\hline Soil $\mathrm{NO}_{3}$ vs. litter $\mathrm{Mg}$ & $\mathrm{ns}$ & $-0.78^{*}$ & $0.71 *$ \\
\hline Soil $\mathrm{P}$ vs. litter $\mathrm{Ca}$ & ns & $-0.69^{*}$ & ns \\
\hline Soil P vs. litter Mg & $\mathrm{ns}$ & $\mathrm{ns}$ & $\mathrm{ns}$ \\
\hline
\end{tabular}

correlated to green leaf $\mathrm{Ca}$ and $\mathrm{Mg}$ concentrations, but negatively correlated to leaf litter $\mathrm{Ca}$ and $\mathrm{Mg}$ concentrations (Table 4). A negative correlation between soil $\mathrm{P}$ and leaf litter Ca concentration was also observed for clone $\mathrm{M} \times \mathrm{B}-915311$. For all clones, soil $\mathrm{NO}_{3}$ and soil $\mathrm{K}$ were not significantly correlated to green foliage $\mathrm{N}$ and $\mathrm{K}$, respectively. However, soil $\mathrm{NO}_{3}$ was strongly and positively correlated to litter $\mathrm{N}$ for clones $\mathrm{M} \times \mathrm{B}-915311$ and $\mathrm{DN} \times \mathrm{M}-915508$, while soil $\mathrm{K}$ was positively correlated to litter $\mathrm{K}$ for clones $\mathrm{D} \times \mathrm{N}-131$ and $\mathrm{M} \times \mathrm{B}-915311$. Soil $\mathrm{P}$ was positively correlated to green leaf $\mathrm{P}$ concentration (only for clones $\mathrm{D} \times \mathrm{N}-131$ and $\mathrm{DN} \times \mathrm{M}$ 915508) and to leaf litter $\mathrm{P}$ concentration (only for clones $\mathrm{D} \times \mathrm{N}-131$ and $\mathrm{M} \times \mathrm{B}-915311)$. Significant positive correlations were equally observed between soil $\mathrm{Mg}$ and green foliage or leaf litter $\mathrm{Mg}$, but only for clones $\mathrm{D} \times \mathrm{N}-131$ and $\mathrm{DN} \times \mathrm{M}-915508$.

\section{Leaf Litter Decay}

For most of the duration of the study, the site and clone effects were significant on the mass remaining of hybrid poplar leaf litter (Table S2). There were only two exceptions, as no site effect was observed on May 16, 2013, after 190 days of in situ incubation, while the clone effect was no longer significant at the end of the experiment, after 732 days (2 years) of incubation (Table S2). After the first sampling point (190 days), the 
Brompton site always had significantly lower leaf litter mass remaining than the two other sites located at higher elevation. Leaf litter mass remaining was generally the highest for clone $\mathrm{DN} \times \mathrm{M}-915508$, while clones $\mathrm{D} \times \mathrm{N}-131$ and $\mathrm{M} \times \mathrm{B}-915311$ had similar patterns of leaf litter mass loss across time (Table S2, Fig. 2). Patterns of mass loss at the site level show that after almost a year (349 days), litter mass remaining ranged from 19.6 to $60.6 \%$ across sites, while it ranged from 4.5 to $35.5 \%$ after 2 years (732 days). At the Brompton site, the decrease in leaf litter mass was especially rapid from May 16, 2013, to October 22, 2013, with 56-62\% of initial litter mass being lost for each clone during this time period (Fig. 2a). At the Brompton site, litter mass remaining after 2 years (732 days) was almost the same for the three clones
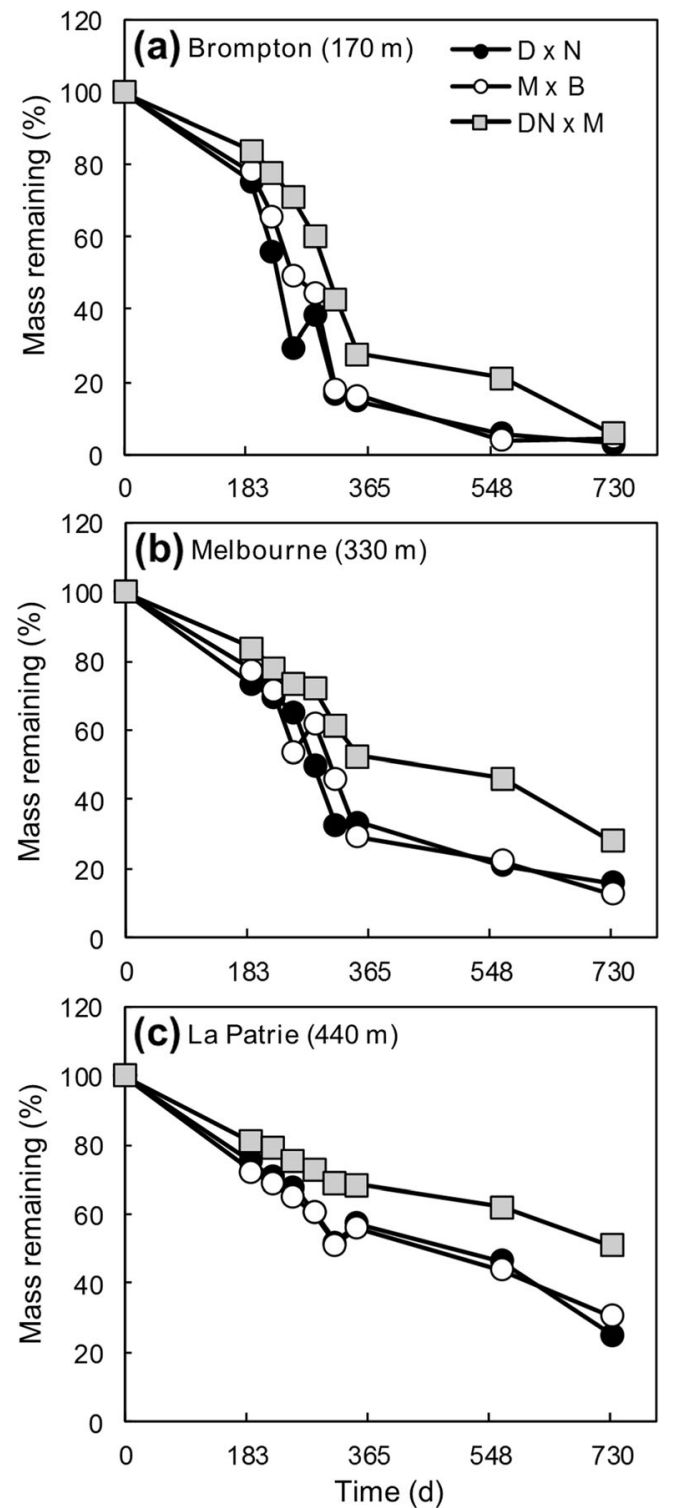

Fig. 2 Percent of leaf litter mass remaining of the three hybrid poplar clones at $\mathbf{a}$ the Brompton site, $\mathbf{b}$ the Melbourne site and $\mathbf{c}$ the La Patrie site, over a 732-day period of in situ incubation (from November 7, 2012, to November 9,2014). Each data point is the mean of three replicates
(3.0\% for $\mathrm{D} \times \mathrm{N}-131,4.5 \%$ for $\mathrm{M} \times \mathrm{B}-915311$ and $5.8 \%$ for $\mathrm{DN} \times \mathrm{M}-915508)$, which contrasts with the results observed at the two other sites (Fig. 2).

For each of the three clones, site elevation was found to be a strong predictor of leaf litter mass remaining $\left(R^{2}=0.71-0.82\right.$ after 349 days and $R^{2}=0.58-0.72$ after 732 days) (Fig. 3). There was one exception where a litter quality indicator was more strongly correlated to mass loss than site elevation, with litter Ca of clone DN $\times$ M-915508 being more strongly correlated to litter mass loss after 349 days $\left(R^{2}=0.77, p<0.01\right)$ than to elevation $\left(R^{2}=0.73, p<0.01\right)$. However, there was a strong covariation between litter Ca of clone DN $\times$ M-915508 and site elevation $(r=-0.87, p<0.01)$.

\section{Discussion}

As we hypothesised, results show significant green foliage and leaf litter nutrient concentration variation across sites for all clones (Table 3). This indicates that most of these traits are under strong environmental control in hybrid poplar clones of different parentages. Variation in foliage and leaf litter nutrient concentrations along site fertility gradients often reflect changes in nutritional or physiological status $[65,66]$, potential nutrient limitations [67], but also trends in nutrient cycling strategies [11, 39]. Our results showed that resorption proficiency (i.e. levels to which nutrients have been reduced in senesced leaves or leaf litter) for growth-limiting nutrients ( $\mathrm{N}$ and $\mathrm{P}$ [67]) increased for all clones when site fertility declined (Tables 1, 2, 3, and 4). Such plasticity in nutrient resorption proficiency suggests that hybrid poplars of different parentages tend to minimise their $\mathrm{N}$ and $\mathrm{P}$ losses in litter fall on the least fertile sites in order to overcome nutrient limitations, thus allowing stable biomass yields across marginal upland sites (Fig. 1). These stable biomass yields achieved by all clones across sites were unexpected, given that soil $\mathrm{NO}_{3}$ and $\mathrm{P}$ availability and site elevation were all strong predictors of yields across longer regional elevation/site fertility gradients [5, 68].

Moreover, we observed a significant clone effect on biomass yield ( $p<0.01$ ) (Fig. 1$)$, many clone effects, and site $\times$ clone interaction effects, on green foliage and leaf litter nutrient concentrations (Table 3), on litter decay (Table S2), but also clone-specific correlation patterns between green foliage and leaf litter nutrient concentrations, and between soil nutrient availability and foliage or leaf litter nutrient concentrations (Table 4). All of these results suggest that the studied clones had specific $\mathrm{C}$ and nutrient cycling strategies and that these clone-specific strategies were not equally effective for sustaining fast growth along a gradient of old field sites.

In agreement with our second hypothesis, clone $\mathrm{D} \times \mathrm{N}-131$ reached the highest nutritional status in green foliage and in leaf litter for most nutrients (Table 3) and, more importantly, 

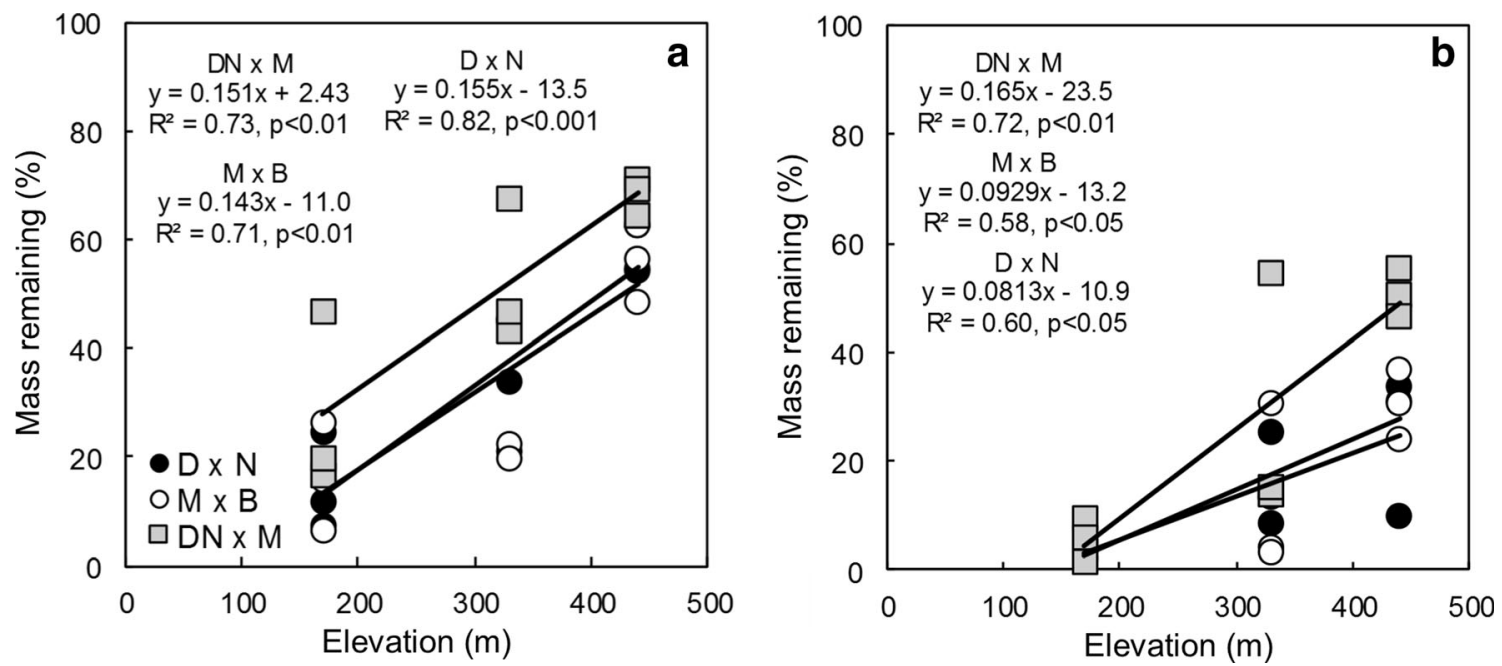

Fig. 3 Covariation between percent mass remaining of hybrid poplar leaf litter and plantation site elevation after a 349 days and b 732 days of in situ incubation. The solid lines represent clone-specific linear least square regressions

the lowest resorption proficiency for growth-limiting nutrients ( $\mathrm{N}$ and $\mathrm{P}$ ). Clone $\mathrm{D} \times \mathrm{N}-131$ was also the least proficient clone at resorbing $\mathrm{K}$ (Table 3), a key nutrient for the regulation of cambial growth and wood formation in poplars [69].

As expected, $\mathrm{D} \times \mathrm{N}-131$ was also the least productive clone after 13 growing seasons (Fig. 1). Being less proficient than the other clones for $\mathrm{N}, \mathrm{P}$ and $\mathrm{K}$ resorption (Table 3), clone $\mathrm{D} \times \mathrm{N}-131$ probably has a much greater dependency on the litter decomposition pathway to fulfill its nutrient requirements. Yet, such a nutrient cycling strategy may rapidly become disadvantageous, even on relatively fertile sites (Brompton), as both understory plants and microorganisms may be limited by nutrient availability, thus competing with trees for nutrients being mineralised during litter decomposition $[11,70]$. The greater nutritional dependency of the $\mathrm{D} \times \mathrm{N}$ hybrid on the litter mineralisation pathway (or its lower ability for nutrient retention) appears to be a plausible explanation to the lack of productivity of this hybrid type outside of warm and rich bottomland sites in the northern temperate zone [51]. Growth and green foliage concentration results for clone $\mathrm{D} \times \mathrm{N}-131$ also agree with the analysis of Grime et al. [15], which shows that high concentrations of macronutrients in green foliage of plants often coincide with an inability to sustain high yield under nutrient-limiting conditions. Thus, clone $\mathrm{D} \times \mathrm{N}-131$ exhibits foliage and litter traits that are typical of species from warm and fertile habitats (high nutrient concentration in green foliage and litter, and rapid litter decay in the short-term) [11], which is consistent with the natural distribution of its parental species $(P$. deltoides and P. nigra), both associated to riparian corridors of large river systems located in bottomland habitats of the warm temperate zone.

Additionally, the high litter $\mathrm{N}$ and $\mathrm{P}$ concentrations and the relatively rapid litter mass loss in the short-term observed for clone D $\times$ N-131 (Fig. 2, Tables 3 and S2) are all traits that could have contributed to plantation soil fertility improvement over the years, as these traits tend to stimulate forest floor decomposition and the release of mineral $\mathrm{N}$ in the soil [11, 37, 39]. Similarly, the high litter $\mathrm{Ca}$ concentration observed for clone $\mathrm{M} \times \mathrm{B}-915311$ at all sites (Table 3 ) could also have led to increases in soil $\mathrm{pH}$, in soil $\mathrm{Ca}$ and in soil base saturation [40]. However, no clone effect was observed on soil nutrient availability and on mineral soil properties after 13 years of poplar cultivation. The small plot size $(12 \times 12 \mathrm{~m}$ per clone $)$ in this experiment inevitably led to litter mixing between plots (clones) at leaf fall, a factor that could have weakened clonespecific litter feedback on soil. Also, litter quality differences between clones were potentially not contrasted enough to trigger feedback on soil properties.

In this study, clone $\mathrm{M} \times \mathrm{B}-915311$ had by far the highest litter $\mathrm{Ca}$ concentration at all sites (Table 3), which may have contributed to stimulating litter decomposition of this clone in the short-term. Thus, although clone $\mathrm{M} \times \mathrm{B}-915311$ had significantly lower litter $\mathrm{N}$ and $\mathrm{P}$ concentrations than clone $\mathrm{D} \times \mathrm{N}-131$ (Table 3), a similar pattern of mass remaining across time was observed for these two clones (Fig. 2, Table S2). High Ca concentrations in leaf litter often have an attractive effect on keystone decomposers with high Ca requirements, such as earthworms (Lumbricus terrestris) and soil molluscs [40, 71, 72], which were frequently observed at all three study sites (J. Fortier, field observations). Thus, the hypothesis that the high quality litter produced by clone $\mathrm{D} \times \mathrm{N}-131$ would decompose the fastest is supported by our data, but it was unexpected that the litter of clones $\mathrm{M} \times \mathrm{B}$ 915311 and $\mathrm{D} \times \mathrm{N}-131$ would have a similar pattern of mass loss through time (Fig. 2).

We had also hypothesised that higher litter mass remaining would be observed for all clones on higher elevation sites, a hypothesis that was validated in this study (Fig. 2, Table S2). Thus, for all clones, leaf litter mass remaining after 1 and 
2 years was strongly and significantly correlated to site elevation (Fig. 3). This is not surprising given that elevation and MAT are strongly correlated regionally [36] and that MAT was the main factor explaining inter-site variations in litter decay of several tree species across Canada [33]. While the clone effect on litter mass remaining was significant over most of the duration of the study (Table S2), a trend likely related to litter quality differences between clones (Table 3 ), this clone effect was no longer significant after 2 years because mass remaining values of all clones converged at the lowest elevation site (Brompton) (Fig. 2, Table S2). These findings corroborate observations from Prescott et al. [25] showing that litter quality differences between fertilised and unfertilised $P$. tremuloides did not significantly affect litter mass loss pattern over 4 years. Long-term litter mass loss experiments in Canada also suggest that after a few years, litter mass remaining of all species tends to converge despite large interspecific variation in short-term decay rate and in initial litter quality $[31,33]$.

Another important, and unexpected, trend observed was the unique capacity of clone $\mathrm{M} \times \mathrm{B}-915311$ to maintain much higher concentrations of divalent cations $(\mathrm{Ca}$ and $\mathrm{Mg}$ ) in its litter than in its green foliage on sites with the lowest soil $\mathrm{NO}_{3}, \mathrm{P}$ and $\mathrm{pH}$ (Melbourne and La Patrie) (Tables 1, 2, and 3). At these sites, litter $\mathrm{Ca}$ of clone $\mathrm{M} \times \mathrm{B}-915311$ was 154 to $170 \%$ higher than its green foliage $\mathrm{Ca}$, while litter $\mathrm{Mg}$ was 139 to $155 \%$ higher than its green foliage $\mathrm{Mg}$ (Table 3). However, on the richer site (Brompton), $\mathrm{Ca}$ and $\mathrm{Mg}$ concentrations were similar or lower in leaf litter when compared to their respective concentrations in green foliage (Table 3). For clone $\mathrm{M} \times \mathrm{B}-915311$, we also observed strong negative correlations between soil $\mathrm{NO}_{3}$ availability and litter $\mathrm{Ca}(r=-0.59, p<0.1)$, between soil $\mathrm{NO}_{3}$ and litter $\mathrm{Mg}(r=-0.78, p<0.05)$, but also between soil $\mathrm{P}$ and litter $\mathrm{Ca}(r=-0.69, p<0.05)$ (Table 4). These results support the idea that as soil $\mathrm{N}$ and $\mathrm{P}$ become limiting resources, which is often the case in the northern temperate zone $[67,73]$, clone $\mathrm{M} \times \mathrm{B}-915311$ resorbs little $\mathrm{Ca}$ and $\mathrm{Mg}$ during senescence in order to increase its divalent base cation inputs to the soil system through litter fall. The negative correlations observed between litter $\mathrm{P}$ and litter $\mathrm{Ca}$, and also between litter $\mathrm{N}$ and litter $\mathrm{Ca}$ or $\mathrm{Mg}$ (Table 4), further suggest that the more proficient clone $\mathrm{M} \times \mathrm{B}-915311$ is at resorbing $\mathrm{N}$ and $\mathrm{P}$, which occurs on lower fertility sites (Tables 1,2, and 3), the higher are the concentrations of divalent cations in its litter. This may reflect a biocycling strategy that aims at preventing further soil acidification, as acidification is an important precursor of many other pedogenic processes negatively affecting soil fertility and hybrid poplar growth (e.g. inhibition of bacterial nitrification, $P$ availability reduction and increased availability of toxicants such as Al) [24, 74]. Higher Ca concentrations in leaf litter vs. green foliage have also been reported in other early successional species that often colonise nutrient-limited habitats (Pinus sylvestris, Pinus concorta, P. tremuloides and Betula pendula) [60].

We also observed a strong positive correlation between litter $\mathrm{N}$ and litter $\mathrm{P}(r=0.85, p<0.01)$, but only for clone $\mathrm{M} \times \mathrm{B}-915311$ (Fig. 2a). Hence, positive association between $\mathrm{N}$ and $\mathrm{P}$ resorption proficiency is clone-dependent in the genus Populus and cannot be generalised as suggested by Killingbeck [12]. Additionally, for clone $\mathrm{M} \times \mathrm{B}-915311$, litter N:P ratio was lower than green foliage N:P ratio only at the Melbourne site, where soil $\mathrm{P}$ availability was the lowest (Tables 2 and 3). This suggests that on sites with greater $\mathrm{P}$ availability (Brompton and La Patrie), clone $\mathrm{M} \times \mathrm{B}-915311$ was more efficient at resorbing $\mathrm{N}$ than $\mathrm{P}$, while the opposite was observed on the site with low soil P availability (Table 3). Such a trend was not observed in the other clones, as they were either more efficient at resorbing $\mathrm{N}$ (clone $\mathrm{D} \times \mathrm{N}-131$ ) or $\mathrm{P}$ (clone $\mathrm{DN} \times \mathrm{M}-915508)$ at all sites (Table 3 ). Thus, the relatively high biomass yields achieved by clone $\mathrm{M} \times \mathrm{B}-915311$ across the studied environmental gradient (Fig. 1) were potentially related to its capacity to maintain high litter $\mathrm{Ca}$ and $\mathrm{Mg}$ concentrations, to increase $\mathrm{N}$ and $\mathrm{P}$ resorption proficiency with declining site fertility, and to modulate the relative proportion of $\mathrm{N}$ and $\mathrm{P}$ that are resorbed in response to soil nutrient availability.

Results also show that clone $\mathrm{DN} \times \mathrm{M}-915508$ was the most proficient at resorbing $\mathrm{N}, \mathrm{P}$ and $\mathrm{K}$ at all plantation sites (Table 3). This clone was also potentially the most efficient at resorbing these nutrients, based on the interpretation of relative nutrient concentration changes between leaf litter and green foliage (Table 3). In addition, clone $\mathrm{DN} \times \mathrm{M}$ 915508 was the only one to have a greater N:P ratio in leaf litter than in its green foliage at all sites, indicating higher resorption efficiency for $\mathrm{P}$ than for $\mathrm{N}$ (Table 3). Yet, contrasted shifts in green foliage vs. leaf litter N:P ratio were also observed across sites for this clone (from 9.7 to 12.2 at Brompton, from 10.9 to 21.4 at La Patrie and from 15.4 to 32.4 at Melbourne) (Table 3). These results suggest that $P$ resorption in clone $\mathrm{DN} \times \mathrm{M}-915508$ becomes proportionally more important than $\mathrm{N}$ resorption on lower soil fertility sites (Melbourne and La Patrie), a possible indication of soil $\mathrm{P}$ limitations for the growth of clone DN $\times$ M-915508 at these sites. In short, being highly proficient and efficient at resorbing key nutrients $(\mathrm{N}, \mathrm{P}$ and $\mathrm{K})$, clone $\mathrm{DN} \times \mathrm{M}-915508$ has a great capacity to minimise nutrient losses in litter fall, especially in the case of $\mathrm{P}$ on lower fertility sites. This greatly reduces its dependency on the decomposition pathway to fulfill its nutritional requirements. Therefore, in a context where soil $\mathrm{P}$ deficiencies are common regionally on upland sites [75], the particularly high ability of clone $\mathrm{DN} \times \mathrm{M}-915508$ for $\mathrm{P}$ resorption could explain its high biomass yields across a variety of old field sites in southern Québec. 


\section{Conclusion}

This study has shown that green foliage and leaf litter traits are under strong genetic and environmental control for hybrid poplars of different parentages. Despite soil fertility and elevation varying between plantation sites, the productivity of each of the poplar clones showed little sensitivity to these changes in environmental conditions. Clone-specific plasticity observed for several foliage and leaf litter traits likely reflects how poplar clones make use of different nutrient cycling strategies to maintain biomass production along a gradient of upland abandoned farmland sites. The two most productive clones (DN $\times$ M-915508 and $\mathrm{M} \times \mathrm{B}-915311)$ were more proficient at resorbing key nutrients $(\mathrm{N}, \mathrm{P}$ and $\mathrm{K})$ at all sites, suggesting that high nutrient resorption proficiency is likely to be an indicator of the ability of some clones to be productive across a wide range of environmental conditions. Also, the unique capacity of clone $\mathrm{M} \times \mathrm{B}-915311$ to maintain high leaf litter $\mathrm{Ca}$ and $\mathrm{Mg}$ concentrations on lower fertility sites (probably to reduce soil acidification and to stimulate organic matter decomposition) is another trait that could allow this clone to be productive on more marginal sites. Finally, despite large differences in initial litter quality between studied clones, patterns of litter mass loss tended to converge with time, and no single litter quality indicator was useful in predicting litter mass remaining in the short-term. At the regional scale, site elevation was found to be a good indicator of litter mass remaining in mature hybrid poplar plantations of the northern temperate zone.

Acknowledgements We gratefully acknowledge funding received from Agriculture and Agri-Food Canada (Agricultural Greenhouse Gas Program). Thanks are also due to all of the owners of the plantation sites (Jean Cloutier, Alfred Labbé, Pierre Labrecque). We greatly appreciated the dedicated help of our field assistants (Joannie Lemelin, Marc-Antoine Pétrin). A special thanks to Harry Isbrucker for providing us with a large amount of space for sample storage and preparation. We acknowledge Dr. R. Bradley and Dr. W. Parsons (University of Sherbrooke) for doing the $\mathrm{C}$ and $\mathrm{N}$ analyses, as well as Anne Déziel of the Berthierville MFFP tree nursery, who provided planting stock. A post-doctoral fellowship from the Fiducie de recherche sur la forêt des Cantons-de-l'Est to Julien Fortier is gratefully acknowledged. Finally, we are grateful to the two anonymous reviewers and to the editorial board member for their constructive comments, which have helped in improving this manuscript.

\section{Compliance with Ethical Standards}

Funding This research was funded by Agriculture and Agri-Food Canada (Agricultural Greenhouse Gas Program).

Conflict of interest The authors declare that they have no conflicts of interest.

Data Availability The dataset collected and analyzed during the current study is available from the corresponding author on reasonable request.
Open Access This article is distributed under the terms of the Creative Commons Attribution 4.0 International License (http:// creativecommons.org/licenses/by/4.0/), which permits unrestricted use, distribution, and reproduction in any medium, provided you give appropriate credit to the original author(s) and the source, provide a link to the Creative Commons license, and indicate if changes were made.

\section{References}

1. FAO (2012) Improving lives with poplars and willows. Synthesis of country progress reports. 24th Session of the International Poplar Commission, Dehradun, India, 30 Oct-2 Nov 2012. Working paper IPC/12. Forest Assessment, Management and Conservation Division, FAO, Rome.

2. Isebrands JG, Aronsson P, Ceulemans MC, Coleman M, Dimitriou ND, Doty S, Gardiner E, Heinsoo K, Johnson JD, Koo YB, Kort J, Kuzovkina J, Licht L, McCracken AR, McIvor I, Mertens P, Perttu K, Riddell-Black D, Robinson B, Scarascia-Mugnozza G, Schroeder WR, Stanturf J, Volk TA, Weih M (2014) Environmental applications of poplars and willows. In: Isebrands JG, Richardson J (eds) Poplars and willows: trees for society and the environment. CABI and FAO, Rome, pp 258-336

3. Perry CH, Miller RC, Brooks KN (2001) Impacts of short-rotation hybrid poplar plantations on regional water yield. For Ecol Manag 143(1-3):143-151

4. Updegraff K, Baughman MJ, Taff SJ (2004) Environmental benefits of cropland conversion to hybrid poplar: economic and policy considerations. Biomass Bioenergy 27(5):411-428

5. Truax B, Gagnon D, Fortier J, Lambert F (2012) Yield in 8 year-old hybrid poplar plantations on abandoned farmland along climatic and soil fertility gradients. For Ecol Manag 267(1):228-239

6. Christersson L (2008) Poplar plantations for paper and energy in the south of Sweden. Biomass Bioenergy 32(11):997-1000

7. Soulères G (1995) Réflexions sur les perspectives actuelles de la populiculture en France. Rev For Franc XLVII:661-674

8. Allwright MR, Taylor G (2016) Molecular breeding for improved second generation bioenergy crops. Trends Plant Sci 21(1):43-54. doi:10.1016/j.tplants.2015.10.002

9. Laudon H, Sponseller R, Lucas R, Futter M, Egnell G, Bishop K, Ågren A, Ring E, Högberg P (2011) Consequences of more intensive forestry for the sustainable management of forest soils and waters. Forests 2(1):243

10. Nielsen UB, Madsen P, Hansen JK, Nord-Larsen T, Nielsen AT (2014) Production potential of 36 poplar clones grown at medium length rotation in Denmark. Biomass Bioenergy 64:99-109. doi:10. 1016/j.biombioe.2014.03.030

11. Aerts R, Chapin FS (1999) The mineral nutrition of wild plants revisited: a re-evaluation of processes and patterns. In: Fitter AH, Raffaelli DG (eds) Advances in ecological research, volume 30. Academic, pp 1-67. doi:10.1016/S0065-2504(08)60016-1

12. Killingbeck KT (1996) Nutrients in senesced leaves: keys to the search for potential resorption and resorption proficiency. Ecol 77(6):1716-1727. doi:10.2307/2265777

13. Eckstein RL, Karlsson PS, Weih M (1999) Leaf life span and nutrient resorption as determinants of plant nutrient conservation in temperate-arctic regions. New Phytol 143(1):177-189. doi:10. 1046/j.1469-8137.1999.00429.x

14. Vergutz L, Manzoni S, Porporato A, Novais RF, Jackson RB (2012) Global resorption efficiencies and concentrations of carbon and nutrients in leaves of terrestrial plants. Ecol Monogr 82(2):205220. doi:10.1890/11-0416.1

15. Grime JP, Thompson K, Hunt R, Hodgson JG, Cornelissen JHC, Rorison IH, Hendry GAF, Ashenden TW, Askew AP, Band SR, 
Booth RE, Bossard CC, Campbell BD, Cooper JEL, Davison AW, Gupta PL, Hall W, Hand DW, Hannah MA, Hillier SH, Hodkinson DJ, Jalili A, Liu Z, Mackey JML, Matthews N, Mowforth MA, Neal AM, Reader RJ, Reiling K, Ross-Fraser W, Spencer RE, Sutton F, Tasker DE, Thorpe PC, Whitehouse J (1997) Integrated screening validates primary axes of specialisation in plants. Oikos 79(2):259-281. doi:10.2307/3546011

16. Salehi A, Ghorbanzadeh N, Salehi M (2013) Soil nutrient status, nutrient return and retranslocation in poplar species and clones in northern Iran. iForest - Biogeosc For 6(6):336-341. doi:10.3832/ ifor0976-006

17. Harvey HP, van den Driessche R (1999) Poplar nutrient resorption in fall or drought: influence of nutrient status and clone. Can J For Res 29(12):1916-1925. doi:10.1139/x99-170

18. Hanson EA (1994) A guide for determining when to fertilize hybrid poplar plantations. USDA Forest Service, North Central Forest Experimental Station. Res. Pap. NC-319

19. Jonczak J, Dziadowiec H, Kacprowicz K, Czarnecki A (2010) An assessment of the influence of poplar clones Hybrid 275 and Robusta on soil cover based on the characteristics of their plant litter fall. Pol J Soil Sc 43(1):9-19

20. Cotrufo MF, De Angelis P, Polle A (2005) Leaf litter production and decomposition in a poplar short-rotation coppice exposed to free air $\mathrm{CO}_{2}$ enrichment (POPFACE). Glob Change Biol 11(6):971-982. doi:10.1111/j.1365-2486.2005.00958.x

21. Driebe EM, Whitham TG (2000) Cottonwood hybridization affects tannin and nitrogen content of leaf litter and alters decomposition. Oecologia 123(1):99-107

22. Dickmann DI, Kuzovkina YA (2008) Poplars and willows of the world, with emphasis on silviculturally important species. FAO Forest Management Division Working Paper IPC/9-2, Rome

23. Coleman M, Tolsted D, Nichols T, Johnson WD, Wene EG, Houghtaling T (2006) Post-establishment fertilization of Minnesota hybrid poplar plantations. Biomass Bioenergy 30(89):740-749

24. Hjelm K, Rytter L (2016) The influence of soil conditions, with focus on soil acidity, on the establishment of poplar (Populus spp.) New For 47(5):731-750. doi:10.1007/s11056-016-9541-9

25. Prescott CE, Kabzems R, Zabek LM (1999) Effects of fertilization on decomposition rate of Populus tremuloides foliar litter in a boreal forest. Can J For Res 29(3):393-397. doi:10.1139/x99-016

26. Fortier J, Gagnon D, Truax B, Lambert F (2010) Nutrient accumulation and carbon sequestration in 6 year-old hybrid poplars in multiclonal agricultural riparian buffer strips. Agric Ecosyst Environ 137(3-4):276-287

27. Lindroth RL, Osier TL, Barnhill HRH, Wood SA (2002) Effects of genotype and nutrient availability on phytochemistry of trembling aspen (Populus tremuloides Michx.) during leaf senescence. Biochem Syst Ecol 30 (4):297-307. doi:10.1016/S0305-1978(01) 00088-6

28. Ericsson T (1994) Nutrient cycling in energy forest plantations. Biomass Bioenergy 6(1):115-121. doi:10.1016/0961-9534(94) 90090-6

29. Schweitzer JA, Bailey JK, Rehill BJ, Martinsen GD, Hart SC, Lindroth RL, Keim P, Whitham TG (2004) Genetically based trait in a dominant tree affects ecosystem processes. Ecol Lett 7(2):127134. doi:10.1111/j.1461-0248.2003.00562.x

30. Madritch M, Donaldson JR, Lindroth RL (2006) Genetic identity of Populus tremuloides litter influences decomposition and nutrient release in a mixed forest stand. Ecosystems 9(4):528-537. doi:10. 1007/s10021-006-0008-2

31. Prescott CE (2010) Litter decomposition: what controls it and how can we alter it to sequester more carbon in forest soils? Biogeochem 101(1-3):133-149. doi:10.1007/s10533-010-9439-0

32. Berg B, Berg MP, Bottner P, Box E, Breymeyer A, Anta RC, Couteaux M, Escudero A, Gallardo A, Kratz W, Madeira M,
Mälkönen E, McClaugherty C, Meentemeyer V, Muñoz F, Piussi P, Remacle J, Santo AV (1993) Litter mass loss rates in pine forests of Europe and eastern United States: some relationships with climate and litter quality. Biogeochem 20(3):127-159. doi:10.1007/ bf00000785

33. Trofymow JA, Moore TR, Titus B, Prescott C, Morrison I, Siltanen M, Smith S, Fyles J, Wein R, Camiré C, Duschene L, Kozak L, Kranabetter M, Visser S (2002) Rates of litter decomposition over 6 years in Canadian forests: influence of litter quality and climate. Can J For Res 32(5):789-804. doi:10.1139/x01-117

34. Zhou G, Guan L, Wei X, Tang X, Liu S, Liu J, Zhang D, Yan J (2008) Factors influencing leaf litter decomposition: an intersite decomposition experiment across China. Plant Soil 311(1):61-72. doi:10.1007/s11104-008-9658-5

35. Taylor BR, Parkinson D (1988) Aspen and pine leaf litter decomposition in laboratory microcosms. II. Interactions of temperature and moisture level. Can J Bot 66(10):1966-1973. doi:10.1139/b88269

36. Villeneuve G-O (1959) Bref aperçu climatique du Québec méridional. Cahiers de géographie du Québec 3(6):153-162

37. Hobbie SE (1992) Effects of plant species on nutrient cycling. Trends Ecol Evol 7(10):336-339. doi:10.1016/0169-5347(92) 90126-V

38. Schimel JP, Cates RG, Ruess R (1998) The role of balsam poplar secondary chemicals in controlling soil nutrient dynamics through succession in the Alaskan Taiga. Biogeochem 42(1):221-234

39. Hobbie SE (2015) Plant species effects on nutrient cycling: revisiting litter feedbacks. Trends Ecol Evol 30(6):357-363. doi: 10.1016/j.tree.2015.03.015

40. Reich PB, Oleksyn J, Modrzynski J, Mrozinski P, Hobbie SE, Eissenstat DM, Chorover J, Chadwick OA, Hale CM, Tjoelker MG (2005) Linking litter calcium, earthworms and soil properties: a common garden test with 14 tree species. Ecol Lett 8(8):811-818. doi:10.1111/j.1461-0248.2005.00779.x

41. Government of Canada (2017) Station results-1981-2010 climate normals and averages. Government of Canada. http:// climate.weather.gc.ca/climate normals/station_select_1981 2010 e.html? searchType $=$ stnProv\&lstProvince $=Q$ QC. Accessed $2017^{-}$Feb 16

42. Robitaille A, Saucier J-P (1998) Paysages régionaux du Québec méridional. Les publications du Québec, Ste-Foy (QC), Canada

43. Périnet P, Gagnon H, Morin S (2010) Liste des clones recommandés de peuplier hybride par sous-région écologique au Québec (mise à jour octobre 2010). Direction de la recherche forestière. MRN, Québec

44. Conseil des productions végétales du Québec (1988) Méthodes d'analyse des sols, des fumiers et des tissus végétaux. AGDEX 533, Québec

45. Bouyoucos GJ (1962) Hydrometer method improved for making particle size analysis of soils. Agron J 54:464-465

46. CRAAQ (2003) Guide de référence en fertilisation, 1re edn. Centre de référence en agriculture et agroalimentaire du Québec, Ste-Foy, QC, Canada

47. Tran TS, Simard RR (1993) Mehlich III-extractable elements. In: Carter MR (ed) Soil sampling and methods of analysis. Canadian Society of Soil Science. Lewis, pp 43-49

48. AOAC (1999) Association of Official Analytical Chemists (AOAC) official methods. Method 984.27: calcium, copper, iron, magnesium, manganese, phosphorus, potassium, sodium and zinc in infant formula - inductively coupled plasma emission spectroscopic. 16th edn. AOAC International

49. Fortier J, Truax B, Gagnon D, Lambert F (2013) Mature hybrid poplar riparian buffers along farm streams produce high yields in response to soil fertility assessed using three methods. Sustainability 5(5):1893-1916 
50. Qian P, Schoenau JJ, Huang WZ (1992) Use of ion exchange membranes in routine soil testing. Comm Soil Sc Plant Anal 23(15): 1791-1804

51. Truax B, Gagnon D, Fortier J, Lambert F (2014) Biomass and volume yield in mature hybrid poplar plantations on temperate abandoned farmland. Forests 5(12):3107-3130

52. Melillo JM, Aber JD, Muratore JF (1982) Nitrogen and lignin control of harwoods leaf litter decomposition dynamics. Ecol 63(3): $621-626$

53. González G, Seastedt TR, Donato Z (2003) Earthworms, arthropods and plant litter decomposition in aspen (Populus tremuloides) and lodgepole pine (Pinus contorta) forests in Colorado, USA. Pedobiologia 47(5-6):863-869. doi:10.1078/ 0031-4056-00272

54. Bocock KL, Gilbert O (1957) The disappearence of leaf litter under different woodland conditions. Plant Soil 9:179-185

55. Beyaert RP, Fox CA (2007) Chapter 40 - assessment of soil biological activity. In: Carter MR, Gregorich EG (eds) Soil sampling and methods of analysis. Second edition. CRC, Boca Raton, pp 527-537. doi:10.1201/9781420005271.ch40

56. Meyer WM, Ostertag R, Cowie RH (2013) Influence of terrestrial molluses on litter decomposition and nutrient release in a hawaiian rain forest. Biotropica 45(6):719-727. doi:10.1111/btp.12057

57. Holdsworth AR, Frelich LE, Reich PB (2008) Litter decomposition in earthworm-invaded northern hardwood forests: role of invasion degree and litter chemistry. Ecoscience 15(4):536-544. doi:10. 2980/15-4-3151

58. Powers JS, Montgomery RA, Adair EC, Brearley FQ, DeWalt SJ, Castanho CT, Chave J, Deinert E, Ganzhorn JU, Gilbert ME, González-Iturbe JA, Bunyavejchewin S, Grau HR, Harms KE, Hiremath A, Iriarte-Vivar S, Manzane E, De Oliveira AA, Poorter L, Ramanamanjato J-B, Salk C, Varela A, Weiblen GD, Lerdau MT (2009) Decomposition in tropical forests: a pan-tropical study of the effects of litter type, litter placement and mesofaunal exclusion across a precipitation gradient. J Ecol 97(4):801-811. doi:10. $1111 / j .1365-2745.2009 .01515 . x$

59. Van Heerwaarden LM, Toet S, Aerts R (2003) Current measures of nutrient resorption efficiency lead to a substantial underestimation of real resorption efficiency: facts and solutions. Oikos 101(3):664669. doi:10.1034/j.1600-0706.2003.12351.x

60. Berg B, McClaugherty C (2008) Plant litter-decomposition, humus formation, carbon sequestration, 2nd edn. Springer, Berlin

61. Reed SC, Townsend AR, Davidson EA, Cleveland CC (2012) Stoichiometric patterns in foliar nutrient resorption across multiple scales. New Phytol 196(1):173-180. doi:10.1111/j.1469-8137. 2012.04249.x

62. Petersen RG (1985) Design and analysis of experiments. MarcelDekker, New York

63. Day RW, Quinn GP (1989) Comparisons of treatments after an analysis of variance in ecology. Ecol Monogr 59(4):433-463. doi: $10.2307 / 1943075$

64. Warton DI, Hui FKC (2011) The arcsine is asinine: the analysis of proportions in ecology. Ecol 92(1):3-10. doi:10.1890/10-0340.1

65. Leech RH, Kim YT (1981) Foliar analysis and DRIS as a guide to fertilizer amendments in poplar plantations. For Chron 57:17-21

66. Reich PB, Oleksyn J (2004) Global patterns of plant leaf N and P in relation to temperature and latitude. PNAS 101(30):11001-11006. doi:10.1073/pnas.0403588101

67. Elser JJ, Bracken MES, Cleland EE, Gruner DS, Harpole WS, Hillebrand H, Ngai JT, Seabloom EW, Shurin JB, Smith JE (2007) Global analysis of nitrogen and phosphorus limitation of primary producers in freshwater, marine and terrestrial ecosystems. Ecol Lett 10(12):1135-1142. doi:10.1111/j.1461-0248.2007. 01113.x

68. Fortier J, Gagnon D, Truax B, Lambert F (2010) Biomass and volume yield after 6 years in multiclonal hybrid poplar riparian buffer strips. Biomass Bioenergy 34:1028-1040

69. Wind C, Arend M, Fromm J (2004) Potassium-dependent cambial growth in poplar. Plant Biol 6(1):30-37. doi:10.1055/s-2004815738

70. Kaye JP, Hart SC (1997) Competition for nitrogen between plants and soil microorganisms. Trends Ecol Evol 12(4):139-143. doi:10. 1016/S0169-5347(97)01001-X

71. Beyer WN, Saari DM (1977) Effect of tree species on the distribution of slugs. J Anim Ecol 46(3):697-702. doi:10.2307/3635

72. Hobbie SE, Reich PB, Oleksyn J, Ogdahl M, Zytkowiak R, Hale C, Karolewski P (2006) Tree species effects on decomposition and forest floor dynamics in a common garden. Ecol 87(9):22882297. doi:10.1890/0012-9658(2006)87[2288:TSEODA]2.0.CO;2

73. Vitousek PM, Howarth RW (1991) Nitrogen limitation on land and in the sea: how can it occur? Biogeochem 13(2):87-115. doi:10. $1007 / \mathrm{bf00002772}$

74. Schaetzl RJ, Anderson S (2005) Soils: genesis and geomorphology. Cambridge University Press, Cambridge

75. Ouimet R, Moore J-D, Duchesne L (2013) Soil thresholds update for diagnosing foliar calcium, potassium, or phosphorus deficiency of sugar maple. Comm Soil Sc Plant Anal 44(16):2408-2427. doi: $10.1080 / 00103624.2013 .803563$ 